\title{
A REVIEW ON MECHANICAL PERFORMANCE OF BANANA FIBER REINFORCED EPOXY COMPOSITES
}

\author{
Prof. Hemant Rajendra Nehete \\ Assistant Professor \\ Department of Mechanical Engineering \\ KCE Society's College of engineering \& Information technology, Jalgaon, Maharashtra
}

\begin{abstract}
World is starting at now focusing on interchange material sources that are condition pleasing what's more, biodegradable in nature. In view of the growing normal concerns, bio composite created out of ordinary fiber and polymeric sap, is one of the late progressions in the business and comprises the current degree of trial work. The utilization of composite materials field is expanding slowly in designing. The composite comprises of essentially two stages for example grid and fiber. The openness of trademark fiber and straightforwardness of gathering have tempted researchers worldwide to endeavor by provincial principles open modest fiber also, to learning their reachability of stronghold conclusions and to what degree they satisfy the obliged specifics of extraordinary reinforced polymer composite focused on basic demand. Fiber strengthened polymer composites has various inclinations, for instance, by and large insignificant exertion of creation, easy to make and preferable quality complexity over impeccable polymer tars due with this explanation fiber fortified polymer composite used inside a variety of arrangement as class of structure material. This paper depict the mechanical conduct of banana fiber fortified polymer composite with the phenomenal references to the effect of fiber stacking and length of fiber on the properties of composites. [1][3][5]
\end{abstract}

\section{INTRODUCTION}

Banana is in Musa family. Banana plant is a huge enduring herb with leaf sheaths that structure surrenders are over to 9 feet in length and 2 feet wide (2.7 meters and 0.61 meter). Its organic products are roughly 4-12 inches (10.2-30.5centimeters). Unique portions of banana trees serve various necessities, counting natural products as nourishment sources, leaves as nourishment wrapping, and stems for fiber and paper mash. It is accessible all through Thailand and Southeast Asian, India, Indonesia, Malaysia, Philippines, Hawaii, and some Pacific islands. This wellspring of strands gives extraordinary quality, utilized by and large in specific items, for example, tea sacks and Japanese yen notes. Normally, banana plants are developed in 3 types; they are nourishment source, enlivening plants, and starch and strands sources (abaca). Abaca fiber has a long history as a main cordage fiber of the world, known as Manila hemp. Abaca is one kind of banana plants. The fiber is acquired from external layers from the stalks of the abaca plant. It is light, solid, and strong. After extraction and dry, it gives a white radiant shading fiber. One specific quality of the abaca fiber over all different filaments of its group is the extraordinary quality and protection from the activity of water, hence its specific versatility for marine ropes. Notwithstanding, abaca's natural product isn't human nourishment source. It is explicitly developed for fiber development. Rather than developing banana tree just for natural product utilization and dispose of the trunks, the utilization of banana strands after the natural products are gathered ought to be investigated. In this manner, the focal points of this exploration is on banana organic product plant.

\section{OBJECTIVE OF THE WORK}

The main objectives of the work are:

1. Creation of short banana fiber based epoxy composites.

2. Assess the mechanical properties, like impact strength, tensile strength flexural strength \& hardness.

3. To consider their impact of fiber stacking and fiber length on mechanical properties of Composites. 
International Journal of Engineering Applied Sciences and Technology, 2020

Vol. 4, Issue 12, ISSN No. 2455-2143, Pages 112-114

Published Online April 2020 in IJEAST (http://www.ijeast.com)

\section{SPECIMEN PREPERATION \& TESTING OF MECHANICAL PROPERTIES}

The materials used for this work are banana fiber, epoxy \& hardener. The banana fiber is acquired from banana plant, which has been gathered from neighborhood sources. The separated banana fiber were consequently sun dried for eight hours at that point dried in stove for 24 hours at $105^{\circ} \mathrm{C}$ to expel free water present in the fiber. The dried fiber were in this manner cut into lengths of 5, 10, $15 \mathrm{~mm}$. The epoxy gums and hardener are secured from Ciba Geigy India Ltd. The banana fiber based epoxy composite is created utilizing hand lay-up process. The molds have been set up with measurements of $180 \times 180 \times 40 \mathrm{~mm} 3$. The banana fiber of various length has been blended in with grid blend with their particular qualities by straightforward mechanical mixing and blend are gradually poured in various molds, keeping the portrayal gauges and view on testing condition. The discharging operator has been use on shape sheet which offer simple to composites expulsion from the form subsequent to restoring the composites. A sliding roller has been utilized to expel the caught air from the uncured composite and shape has been shut at temperature $30^{\circ} \mathrm{C}$ term 24 hour. The consistent heap of $50 \mathrm{~kg}$ is applied on the shape where the blend of the banana, epoxy pitch and hardener has been poured. After relieving, the example has been taken out from the shape. The composite material has been cut in reasonable measurements with assistance of zig saw for mechanical tests according to the ASTM models.

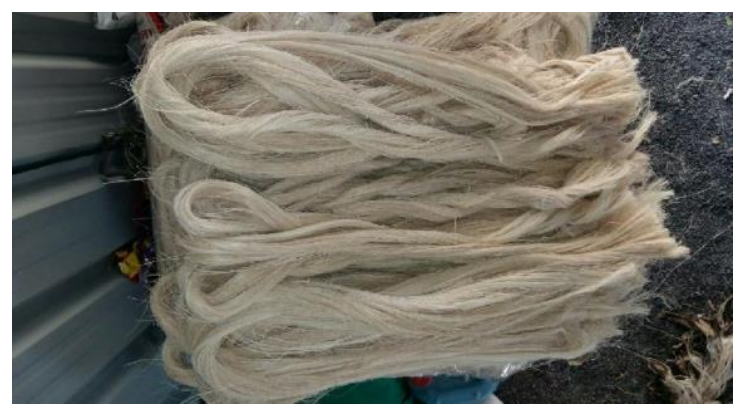

Fig 1 Fabricated banana fiber reinforced epoxy composites

Testing of mechanical properties

1. Tensile strength-This test is carried out on Instron machine

2. Flexural strength test- Three point bend test method is used for testing flexural test on Universal testing machine Instron 1195.
3. Impact strength- This test is carried out on impact testing machine

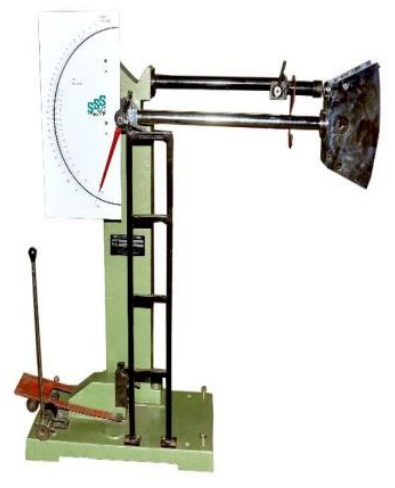

Fig 2 Impact testing machine

4. Hardness test- This test is carried out on Vikers hardness testing machine.

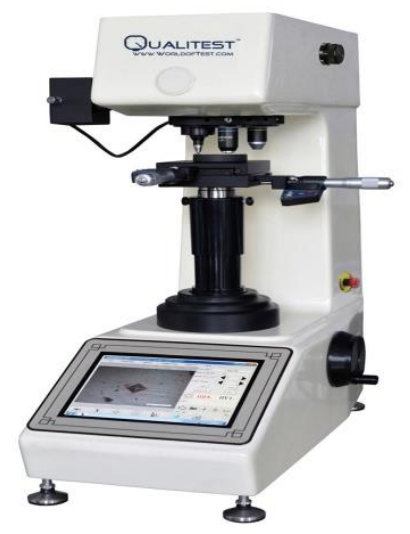

Fig 3Vikers hardness testing machine

\section{RESULT}

Mechanical properties like tensile strength, flexural strength, impact strength and hardness depends on fiber content and length. Tensile strength of composites increases with increase in fiber length \& loadings. when fiber length increases the flexural strength of the fabricated composites first increases up to some length and then decreases. When fiber loading increase then flexural strength increase up to fiber loading and then decreases. As fiber length increases, impact strength also increases. The hardness value increases when increase in fiber length. 


\section{International Journal of Engineering Applied Sciences and Technology, 2020 \\ Vol. 4, Issue 12, ISSN No. 2455-2143, Pages 112-114 \\ Published Online April 2020 in IJEAST (http://www.ijeast.com)}

\section{FUTURE SCOPE}

By adding different fibers, a hybrid composite can be prepared. Also we can do FEA analysis for this composites.

\section{CONCLUSION}

The manufacture of banana fiber based epoxy composites with various stacking of fiber what's more, various lengths of fiber is conceivable by hand lay-up process. From the review, it has been seen that fiber stacking and length has significant impact on the mechanical properties of the composites like as hardness, tensile strength, flexural strength and impact strength.

\section{ACKNOWLEDGEMENT}

Author is thankful for Head of dept and all teaching staff of Mechanical engg dept for their guidance and constant inspiration for the work. Also author is very much thankful to parents and friends for their support.

\section{REFERENCES}

1. Aziz M. A., Mansur M A, (1983) Study of Bamboo-Mesh Reinforced Cement Composites, International Journal of Cement Composites and Lightweight Concrete, pp.165-171.

2. 2.Mohini M. S., Muhammad P, (2003) Carbon Storage Potential in Natural Fiber Composites,vResource Conservation and Recycling, pp. 325-340.

3. Shibata S., Cao Y., Fukumoto I (2006), Lightweight Laminate Composites made from Kenaf and Polypropylene Fibres, Polymer Testing, pp. 142-148.

4. Shankar P. S., Reddy K.T., Sekhar V. C (2013), chanical Performance and Analysis of Banana Fiber Reinforced Epoxy Composites, International Journal of Recent Trends in Mechanical Engineering, pp.1-10.

5. Sumaila M., Amber I., Bawa M. (2013), Effect of Fiber Length on the Physical and Mechanical Properties of Random Oriented, Nonwoven Short banana (Musa Balbisiana) Fiber/Epoxy Composite, Asian Journal of Natural \& Applied Sciences, pp. 39-49.

6. Merlini C., Soldi V. , Barra G. M. O.,(2011) Influence of Fiber Surface Treatment and Length on Physico-Chemical Properties of Short Random Banana Fiber-Reinforced Castor Oil
Polyurethane Composites, Polymer Testing), pp. 833-840.

7. Dhieb H., Buijnsters J. G., Eddoumy F., Vázquez L., Celis J.P., (2013) Surface and SubSurface Degradation of Unidirectional Carbon Fiber Reinforced Epoxy Composites Under Dry and Wet Reciprocating Sliding, Composites Part A: Applied Science and Manufacturing, pp. 5362.

8. Satyanarayana K. G., Sukumaran K., Pavithran C., Mukherjee P. S., Pillai S. G. K., Natural Fiber-Polymer Composites, Cement (1990) and Concrete Composites, pp. 117-136.

9. Kulkarni A. G., Rohatgi P. K., Satyanarayana K. G., Sukumaran K., Pillai S. G. K., (1986) Fabrication and Properties of Natural FiberReinforced Polyester Composites, Composites, pp. 329-333.

10. Kularni A. G., Satyanaranaya K. G., Rohatgi P. K., Vijayan K., (1983) Mechanical Properties of

11. Banana Fiber, Journal of Material Science pp. 2290-2296.

12. Joseph S., Sreekala M. S., Oommena Z., Koshy P., Thomas S. (2002), A Comparison of the

13. Mechanical Properties of Phenol Formaldehyde, Composites Reinforced with Banana

14. Fibres and Glass Fibres, Composites Science and Technology, pp. 1857-1868.

15. 12. Selzer R., Friedrich K, (1996) Mechanical Properties and Failure Behavior of Carbon Fibre-

16. Reinforced Polymer Composites under the Influence of Moisture, Composites Part A:

17. Applied Science and Manufacturing, pp. 595604. 